\title{
Pengaruh Rasio Profitabilitas, Leverage dan Kebijakan Dividen terhadap Nilai Perusahaan \\ (Studi pada Sektor Perbankan di Bursa Efek Indonesia)
}

\author{
Ida Ayu Dinda Priyanka Maharani(1) \\ ${ }^{(1)}$ Program Studi Manajemen Fakultas Ekonomi dan Bisnis Universitas Warmadewa \\ Email: iadindapriyanka@gmail.com
}

\begin{tabular}{|l|l|l|}
\hline Diterima: 10 Desember 2020 & Direvisi: 19 Januari 2021 & Disetujui: 21 Januari 2021 \\
\hline
\end{tabular}

\begin{abstract}
This study discusses the relationship between profitability ratios, leverage and dividend policy on firm value in the banking sector on the Indonesia Stock Exchange. The banking sector was chosen because the banking sector is one of the fastest growing sectors and has promising long-term business prospects. The high value of the company will affect the level of prosperity of shareholders. Several factors affect firm value, namely profitability, leverage, and dividend policy, which are factors that can be controlled by the company. This study uses Dividend Irrelevance Theory and Bird in The Hand Theory as the main theory in explaining the importance of profitability ratios, leverage ratios and dividend policies in increasing firm value. The analysis technique uses the Path Analysis estimation technique. The results of the study found that leverage has a negative and significant effect on firm value and leverage has a negative effect on dividend policy.
\end{abstract}

Keyword: profitability, leverage, dividend policy, firm value, banking sector

\section{Pendahuluan}

Pasar modal membawa perkembangan yang cukup penting dalam perekonomian. Sehingga pasar modal dipandang sebagai salah satu barometer kondisi perekonomian suatu negara termasuk Indonesia. Melakukan investasi melalui pasar modal, para investor mendapat kesempatan untuk memperoleh hasil (return) yang diharapkan (Sunarya, 2015). Aktivitas investasi di pasar modal ini terdiversifikasi ke dalam berbagai sektor. Sektor perbankan merupakan salah satu sektor yang tumbuh pesat dan memiliki prospek bisnis jangka panjang yang menjanjikan. Kondisi persaingan di sektor perbankan yang semakin kompetitif, menyebabkan bank harus terus berupaya memperbaiki kinerja keuangannya. Kinerja keuangan yang baik akan meningkatkan nilai perusahaan (Kohlsceen et al., 2018). Pentingnya nilai perusahaan membuat sektor perbankan untuk memaksimalkan nilai perusahaan, sehingga meningkatkan permintaan investor terhadap sahamnya. Nilai perusahaan diartikan sebagai harga yang bersedia dibayar oleh calon investor seandainya suatu perusahaan akan dijual (Sartono, 2014).Tingginya nilai perusahaan akan mempengaruhi tingkat kemakmuran pemegang saham. Beberapa faktor yang mempengaruhi nilai 
perusahaan, yaitu profitabilitas, laverage, serta kebijakan dividen yang termasuk faktor yang dapat dikendalikan oleh perusahaan (Goblin et al., 2013). Profitabilitas menunjukkan kemampuan perusahaan memperoleh laba dalam hubungannya dengan penjualan, total aktiva maupun modal sendiri (Sartono, 2014). Hakim dan Sugianto (2018) menemukan bahwa profitabilitas berpengaruh positif dan signifikan terhadap nilai perusahaan.Hal ini menyimpulkan bahwa profitabilitas memiliki hubungan positif secara langsung terhadap nilai perusahaan.

Leverage merupakan kebijakan pendanaan bersumber dari eksternal yang menunjukkan berapa besar perusahaan membiayai kebutuhan dananya. Onyenwe dan Glory (2017) menemukan bahwa leverage berpengaruh positif dan signifikan terhadap nilai perusahaan.Penggunaan hutang meningkatkan efisiensi manajerial dan manajer perusahaan harus memastikan untuk menghasilkan keuntungan lebih besar untuk membayar bunga. Kebijakan dividen merupakan kebjakan perusahaan dalam menentukan laba yang diperoleh akan dibagikan kepada pemegang saham sebagai dividen ataulaba tersebut ditahan untuk membiayai investasi dimasa mendatang (Sartono, 2014). Dengan tingginya pembayaran dividen kepada pemegang saham akan meningkatkan nilai perusahaan. Studi sebelumnya yang dilakukan oleh Afzal dan Rohman (2015) menemukan kebijakan dividen berpengaruh postif dan signifikan terhadap nilai perusahaan.

Berdasarkan hasil penelitian sebelumnya, research gap dan rekomendasi dari Velnampy et al. (2014), maka tujuan pada penelitian ini yaitu mengkaji hubungan rasio profitabilitas, leverage dan kebijakan dividen dalam mempengaruhi nilai perusahaan pada sector perbankan di Bursa Efek Indonesia.

\section{Telaah Literatur dan Kajian Pustaka}

\section{Dividen Irrelevance Theory}

Teori dividen tidak relevan dikemukakan oleh Miller dan Modigliani (1961). Menurut teori ini bahwa kebijakan dividen tidak mempengaruhi nilai perusahaan karena rasio pembayaran dividen hanyalah rincian dan tidak mempengaruhi kesejahteraan pemegang saham. Nilai sebuah perusahaan hanya bergantung pada laba yang dihasilkan dari asetnya, bukan tentang laba yang dipisahkanantara dividen dan laba ditahan. Teori bird in the hand adalah salah satu teori dalam kebijakan deviden yang dikembangkan oleh Myron Gordon (1956) dan John Lintner (1962). Menurut teori ini bahwa pemegang saham lebih menyukai dividen tinggi dibandingkan dividen dibagikan di masa yang akan datang atau capital gain.

\section{Nilai Perusahaan}

Keown et al. (2004) mendefinisikan nilai perusahaan adalah nilai pasar atas surat berharga hutang dan ekuiti perusahaan yang beredar. Gitman (2009) mendefinisikan nilai perusahaan 
sebagai nilai aktual per lembar saham yang akan diterima apabila aset perusahaan dijual sesuai harga saham. Sujoko dan Soebiantoro (2016) menyatakan bahwa nilai perusahaan merupakan persepsi investor terhadap perusahaan yang selalu dikaitkan dengan harga saham. Husnan dan Pujiastuti (2015) menyatakan bahwa nilai perusahaan merupakan harga yang bersedia dibayar oleh calon pembeli apabila perusahaan dijual. Berdasarkan definisi tersebut dapat dirangkum bahwa nilai perusahaan adalah persepsi investor yang selalu dikaitkan dengan harga saham.

\section{Profitabilitas}

Sartono (2014) menyatakan bahwa profitabilitas adalah kemampuan perusahaan dalam memperoleh laba dalam hubungan dengan penjualan, total aktiva maupun modal sendiri. Brigham dan Houston (2006) mendefinisikan profitabilitas adalah hasil bersih dari serangkaian kebijakan dan keputusan. Profitabilitas yang tinggi menunjukkan perusahaan memiliki prospek yang baik, sehingga investor akan merespon positif sinyal tersebut dan nilai perusahaan akan meningkat (Sujoko dan Soebiantoro, 2016). Semakin besar laba yang diperoleh perusahaan akan mampu meningkatkan nilai perusahaan (Wijaya dan Sedana, 2015).

\section{Leverage}

Curran (1987) menyatakan bahwa leverage adalah hubungan antara dana dan ekuitas pemegang saham karena dihitung dalam rasio hutang terhadap ekuitas. Munawir (2002) mengemukakan bahwa leverage adalah semua kewajiban keuangan perusahaan kepada pihak lain yang belum terpenuhi, dimana leverage merupakan sumber dana atau modal perusahaan yang berasal dari kreditor. Sedangkan Bressan (2017) mendefinisikan leverage adalah kemampuan perusahaan untuk menggunakan biaya keuangan tetap untuk memperbesar efek perubahan dalam laba sebelum bunga dan pajak atas laba per saham perusahaan. Berdasarkan pengertian tersebut, dapat disimpulkan bahwa leverage adalah kemampuan perusahaan untuk memenuhi seluruh kewajiban finansialnya yang terdiri dari hutang jangka pendek dan hutang jangka panjang

\section{Kebijakan Dividen}

Kebijakan dividen merupakan keputusan yang berkaitan dengan penggunaan laba yang menjadi hak pemegang saham dan laba tersebut dapat dibagi sebagai dividen atau laba yang ditahan untuk diinvestasikan kembali. Menurut Sartono (2014) kebijakan dividen adalah keputusan apakah laba yang diperoleh perusahaan akan dibagikan kepada pemegang saham sebagai dividen atau ditahan dalam bentuk laba ditahan guna pembiayaan investasi di masa yang akan datang. Masum (2014) mendefinisikan kebijakan dividen adalah keputusan pembiayaan utama yang melibatkan para pemegang saham dalam pembayaran dan pengembalian investasi mereka. 
Pengaruh Profitabilitas terhadap Nilai Perusahaan

Profitabilitas menunjukan kemampuan perusahaan memperoleh laba atau ukuran efektivitas pengelolaan manajemen perusahaan (Wiagustini, 2010). Sejumlah peneliti sebelumnya, seperti Naceur dan Goaied (2012) menemukan bahwa profitabilitas berpengaruh positif dan signifikan terhadap nilai perusahaan. Martini et al. (2014) menemukan bahwa profitabilitas perusahaan yang lebih tinggi dapat meningkatkan nilai perusahaan untuk menghasilkan laba, sehingga akan berpengaruhterhadap nilai perusahaan yang tinggi. Kurniawan (2016) menemukan bahwa profitabilitas yang diukur dengan Return on Equity (ROE) berpengaruh signifikan terhadap nilai perusahaan. Hakim dan Sugianto (2018) menemukan bahwa profitabilitas berpengaruh positif dan signifikan terhadap nilai perusahaan. Berdasarkan uraian diatas, maka dapat diajukan hipotesis:

\section{$H_{1}$ : Profitabilitas berpengaruh positif dan signifikan terhadap nilai perusahaan.}

Pengaruh Leverage terhadap Nilai Perusahaan

Leverage menunjukkan besarnya modal sendiri yang dijadikan untuk jaminan hutang (Kasmir, 2010). Kajola (2008) menyatakan bahwa jika perusahaan menggunakan leverage yang tinggi mengakibatkan nilai perusahaan menurun. Beberapa penelitian sebelumnya, seperti Bhardwaj (2015) menemukan bahwa laverage berpengaruh signifikan terhadap nilai perusahaan. Ramadan (2015) menemukan bahwa tingkat laverage perusahaan berpengaruh signifikan terhadap nilai perusahaan yang terdaftar di di Amman Stock Exchange Yordania. Adetunji et al. (2016) menemukan bahwa ada hubungan yang signifikan antara leverage keuangan dan nilai perusahaan. Berdasarkan uraian tersebut, maka dapat diajukan hipotesis:

\section{$\mathrm{H}_{2}$ : Leverage berpengaruh positif dan signifikan terhadap nilai perusahaan.}

Pengaruh Profitabilitas terhadap Kebijakan Dividen

Pembayaran dividen yang optimal dapat dilihat sebagai tanda dari profitabilitas di masa yang akan datang. Perusahaan yang dapat menjaga atau bahkan meningkatkan laba dapat dilihat sebagai sinyal positif oleh investor yangberhubungan dengan kinerja perusahaan. Migwi (2015) menemukan proftabilitas berpengaruh positif dan signifikan terhadap kebijakan dividen pada bank di Kenya. Sisca (2016) menemukan bahwa proftabilitas berpengaruh positif terhadap kebijakan dividen pada perusahaan manufaktur yang terdaftar di BEI. Tamrin et al. (2017) menemukan bahwa proftabilitas berpengaruh positif dan signifikan terhadap kebijakan dividen. Berdasarkan uraian tersebut, maka dapat diajukan hipotesis:

\section{H3: Profitabilitas berpengaruh positif dan signifikan terhadap kebijakan dividen.}

Pengaruh Leverage terhadap Kebijakan Dividen 
Kebijakan dividen adalah keputusan apakah laba yang diperoleh perusahaan akan dibagikan kepada pemegang saham sebagai dividen atau ditahan dalam bentuk laba ditahan guna pembiayaan investasi di masa yang akan datang (Sartono, 2008). Asif et al. (2011) menemukan bahwa leverage berpengaruh positif dan signifikan terhadap kebijakan dividen. Sriwahyuni dan Wihandaru (2016) menemukan bahwa leverage berpengaruh positif dan signifikan terhadap kebijakan dividen pada perusahaan manufaktur yang terdaftar di BEI periode 2010-2014. Whidyasmoro dan Mahastanti (2016) menemukan bahwa leverage berpengaruh positif dan signifikan terhadap kebijakan dividen pada perusahaan yang tergabung dalam Jakarta Stock Industrial Classification yang terdaftar di BEI tahun 2010. Berdasarkan uraian tersebut, maka dapat diajukan hipotesis:

\section{H4: Leverage berpengaruh positif dan signifikan terhadap kebijakan dividen.}

Pengaruh Kebijakan Dividen terhadap Nilai Perusahaan

Perusahaan yang membayar dividen stabil dari waktu ke waktu kemungkinan dinilai lebih baik daripada perusahaan yang membayar dividen berfluktuasi (Oliver dan Iniviei, 2016). Topal (2014) menemukan bahwa terdapat hubungan yang signifikan antara pembayaran dividen dengan nilai perusahaan. Rachid dan Wiame (2016) menemukan bahwa ada hubungan yang signifikan antara pembayaran dividen dan total aset dengan nilai perusahaan. Egbeonu et al. (2016) menemukan bahwa kebijakan dividen per saham berpengaruh positif dan signifikan terhadap nilai saham perusahaan. Berdasarkan uraian tersebut, maka dapat diajukan hipotesis:

\section{H5: Kebijakan dividen berpengaruh positif dan signifikan terhadap nilai perusahaan.}

\section{Metode Penelitian}

Penelitian ini dilakukan pada perusahaan sektor perbankan yang terdaftar di Bursa Efek Indonesia. Sektor perbanka dipilih karena merupakan salah satu sektor yang tumbuh pesat dan memiliki prospek bisnis jangka panjang yang menjanjikan. Kondisi persaingan di sektor perbankan yang semakin kompetitif, menyebabkan bank harus terus berupaya memperbaiki kinerja keuangannya. Kinerja keuangan yang baik akan meningkatkan nilai perusahaan Jumlah populasi adalah sebanyak 40 perusahaan bank. Sampel adalah bagian dari jumlah dan karateristik yang dimiliki oleh populasi tersebut (Sugiyono, 2010). Metode pengambilan sampel pada penelitian ini berdasarkan purposive sampling Jumlah sampel yang diambil berdasarkan beberapa kriteria sebagai berikut:

a. Perusahaan sektor perbankan yang mempublikasikan laporan keuangan yang telah diaudit periode 2017-2019

b. Laporan keuangan perusahaan sektor perbankan tahun 2017-2019 dalam bentuk Rupiah.

c. Perusahaan sektor perbankan secara rutin membagikan dividen selama periode 2017-2019. 
Berdasarkan kriteria tersebut, maka sampel yang diambil pada penelitian ini adalah sebanyak 10 perusahaan dari 40 perusahaan sektor perbankan yang terdaftar di Bursa Efek Indonesia periode 2017-2019.

Metode pengumpulan data dilakukan dengan cara observasi non partisipan, yaitu dengan cara mengumpulkan, mencatat, dan mengkaji data sekunder berupa laporan keuangan perusahaan perbankan yang dipublikasikan oleh Bursa Efek Indonesia melalui situs www.idx.com untuk periode tahun 2017-2019. Jumlah pengamatan yang dilakukan penelitian ini adalah sepuluh perusahaan sektor perbankan dan empat tahun periode peneliti. Permasalahan yang memiliki karakteristik hubungan berjenjang dan jenis variabel tersebut, maka teknik analisis menggunakan permasalahan simultan dengan teknik estimasi Path Analysis. Program aplikasi SPSS versi 21.0 digunakan untuk membantu dalam menganalisis data yang digunakan dalam penelitian ini.

\section{Hasil Penelitian dan Pembahasan}

Model path analysis digunakan untuk menganalisis pola hubungan antar variabel dengan tujuan mengetahui pengaruh langsung maupun tidak langsung seperangkat variabel bebas (eksogen) terhadap variabel terikat (endogen). Model path analysis adalah pola hubungan sebab akibat atau " a set of hypothesized asymmetric relation among the variables" (Riduwan dan Engkos, 2012).

Tabel 1. Analisis Path Koefisien Profitabilitas $\left(\mathbf{X}_{1}\right)$, Leverage $\left(\mathbf{X}_{2}\right)$, Kebijakan Dividen $\left(\mathbf{X}_{3}\right)$

\begin{tabular}{|c|c|c|c|c|c|c|c|c|c|c|c|c|}
\hline \multicolumn{13}{|c|}{ Coefficients $^{a}$} \\
\hline \multirow[t]{2}{*}{ Model } & \multicolumn{2}{|c|}{$\begin{array}{l}\text { Unstandardized } \\
\text { Coefficients }\end{array}$} & \multirow{2}{*}{$\begin{array}{c}\text { Standardized } \\
\text { Coefficients } \\
\text { Beta }\end{array}$} & \multirow[t]{2}{*}{$\mathrm{T}$} & \multirow[t]{2}{*}{ Sig. } & \multicolumn{2}{|c|}{$\begin{array}{c}95,0 \% \\
\text { Confidence } \\
\text { Interval for B }\end{array}$} & \multicolumn{3}{|c|}{ Correlations } & \multicolumn{2}{|c|}{$\begin{array}{l}\text { Collinearity } \\
\text { Statistics }\end{array}$} \\
\hline & B & $\begin{array}{l}\text { Std. } \\
\text { Error }\end{array}$ & & & & $\begin{array}{l}\text { Lower } \\
\text { Bound }\end{array}$ & $\begin{array}{l}\text { Upper } \\
\text { Bound }\end{array}$ & $\begin{array}{l}\text { Zero- } \\
\text { order }\end{array}$ & Partial & Part & Tolerance & VIF \\
\hline $1^{\text {(Constant) }}$ & 1,204 & ,221 & & 5,451 & ,000 & ,757 & 1,652 & & & & & \\
\hline LX1 & ,264 & ,147 & ,282 & 1,794 &, 081 &,- 034 &, 562 & ,279 & ,283 & ,282 & ,999 & 1,001 \\
\hline LX2 &,- 109 &, 191 &,- 090 &,- 573 &, 570 &,- 496 & ,278 &,- 080 &,- 094 &,- 090 & ,999 & 1,001 \\
\hline
\end{tabular}

a. Dependent Variable: LY1

Berdasarkan perhitungan analisis jalur (path) pada tabel 1 diketahui bahwa koefisien profitabilitas terhadap kebijakan dividen sebesar 0,282 dengan signifikansi sebesar 0,081 yang lebih kecil dari tingkat signifikansi yang digunakan yaitu $\alpha=0,050$. Koefisien leverage terhadap kebijakan dividen sebesar -0,090 dengan signifikansi sebesar 0,570 yang lebih besar dari tingkat signifikansi yang digunakan yaitu $\alpha=0,050$.

Tabel 2. Koefisien determinasi $\left(\mathbf{R}^{2}\right)$ Profitabilitas $\left(\mathbf{X}_{1}\right)$, Leverage $\left(\mathbf{X}_{2}\right)$, Kebijakan Dividen $\left(\mathrm{X}_{3}\right)$ 


\begin{tabular}{|c|c|c|c|c|c|c|c|c|c|c|}
\hline \multirow[t]{2}{*}{ Model } & \multirow[t]{2}{*}{$\mathrm{R}$} & \multirow{2}{*}{$\begin{array}{c}\mathrm{R} \\
\text { Square }\end{array}$} & \multirow{2}{*}{$\begin{array}{l}\text { Adjusted R } \\
\text { Square }\end{array}$} & \multirow{2}{*}{$\begin{array}{l}\text { Std. Error } \\
\text { of the } \\
\text { Estimate }\end{array}$} & \multicolumn{5}{|c|}{ Change Statistics } & \multirow{2}{*}{$\begin{array}{l}\text { Durbin- } \\
\text { Watson }\end{array}$} \\
\hline & & & & & $\begin{array}{c}\text { R Square } \\
\text { Change }\end{array}$ & $\begin{array}{c}\mathrm{F} \\
\text { Change }\end{array}$ & df1 & df2 & $\begin{array}{c}\text { Sig. F } \\
\text { Change }\end{array}$ & \\
\hline 1 & $293^{a}$ & ,086 & ,037 & ,22580 &, 086 & 1,739 & 2 & 37 & , 190 & 2,063 \\
\hline
\end{tabular}

a. Predictors: (Constant), LX2, LX1

b. Dependent Variable: LY1

Berdasarkan analisis koefisien diterminasi pada tabel 2 diketahui bahwa nilai $R$ Square sebesar 0,086 $(8,6 \%)$ yang berarti variasi profitabilitas dan leverage dapat menjelaskan variasi kebijakan dividen pada perusahaan sektor perbankan yang terdaftar di BEI periode tahun 20172019 sebesar 8,6\% dan sisanya sebesar 91,4\% dijelaskan oleh faktor lainnya yang tidak diteliti.

Berdasarkan Tabel 3, hasil analisis jalur (path) diketahui koefisien profitabilitas terhadap nilai perusahaan sebesar 0,529 dengan signifikansi sebesar 0,000 yang lebih kecil dari tingkat signifikansi yang digunakan yaitu $\alpha=0,050$. Koefisien leverage terhadap nilai perusahaan sebesar -0,421 dan signifikansi sebesar 0,002 yang lebih kecil dari tingkat signifikansi yang digunakan yaitu $\alpha=0,050$. Sedangkan koefisien kebijakan dividen terhadap nilai perusahaan sebesar $-0,127$ dan signifikansi sebesar 0,347 lebih besar dari tingkat signifikansi yang digunakan yaitu $\alpha=0,050$.

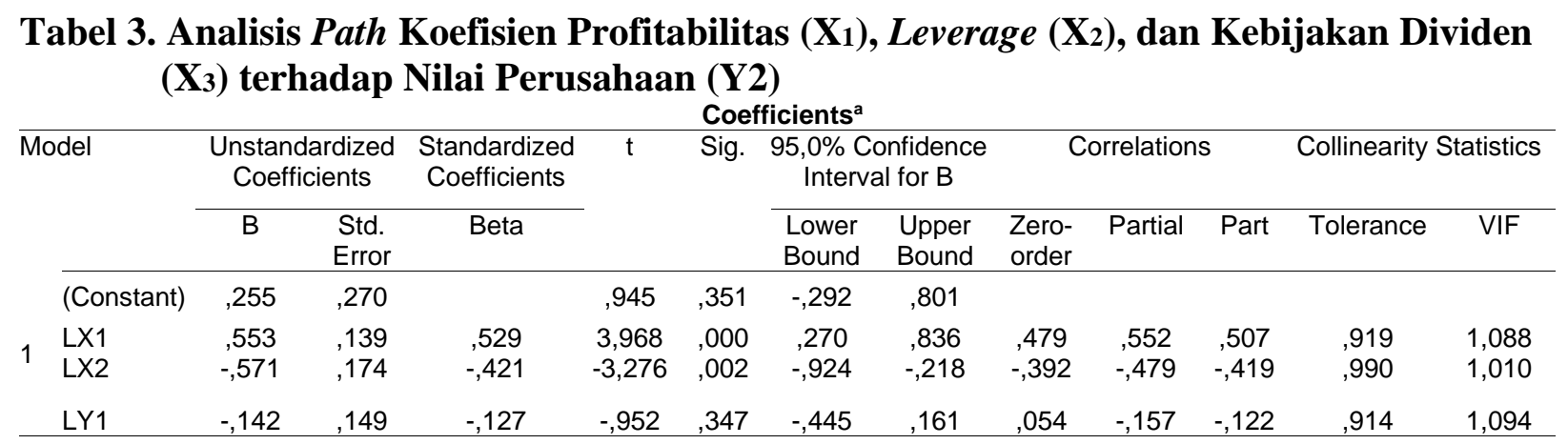

a. Dependent Variable: LY2

Hasil uji berdasarkan analisis jalur ( $p a t h$ ) diketahui bahwa profitabilitas berpengaruh positif dan signifikan terhadap nilai perusahaan. Hal ini dapat dilihat dari besarnya pengaruh profitabilitas terhadap nilai perusahaan yaitu sebesar 0,529 dengan signifikansi sebesar 0,000 lebih kecil dari tingkat signifikansi yang digunakan yaitu $\alpha=0,05$. Dengan demikian, hipotesis 1 pada penelitian ini yang menyatakan bahwa profitabilitas berpengaruh positif dan signifikan terhadap nilai perusahaan diterima. Pada sektor perbankan, sumber keuntungan bank berasal dari deposit yang merupakan simpanan nasabah dengan perjanjian tertentu dengan pihak perbankan (Taswan, 2010). Melalui simpanan nasabah, bank akan mendapatkan dana lebih yang digunakan untuk memberikan kredit kepada pihak-pihak yang membutuhkan yang dibebani bunga pinjaman. Bunga pinjaman biasanya lebih besar dari bunga simpanan, sehingga bank bisa menghasilkan keuntungan.Semakin baik pertumbuhan profitabilitas perusahaan, maka prospek perusahaan di masa yang akan datang dinilai semakin baik. Penelitian ini mendukung hasil studi sebelumnya yang menemukan bahwa 
proftabilitas berpengaruh positif dan signifikan terhadap nilai perusahaan (Naceur dan Goaied, 2012; Martini et al., 2014; Kurniawan, 2016; Sucuahi dan Cambarihan, 2016, dan Hakim dan Sugianto, 2018).

Hasil uji berdasarkan analisis jalur (path) diketahui bahwa leverage berpengaruh negatif dan signifikan terhadap nilai perusahaan. Hal ini dapat dilihat dari besarnya pengaruh leverage terhadap nilai perusahaan sebesar -0,421dengan signifikansi sebesar 0,002 yang lebih kecil dari tingkat signifikansi yang digunakan yaitu $\alpha=0,05$. Oleh karena itu, hipotesis 2 pada penelitian ini yang menyatakan bahwa leverage berpengaruh positif dan signifikan terhadap nilai perusahaan ditolak. Semakin besar bank menggunakan dana dari pihak eksternal, maka akan berdampak bagi pemegang saham, yaitu menurunnya nilai investasi mereka karena harga saham yang turun, sehingga akan berpengaruh terhadap menurunnya nilai perusahaan. Demirguc-Kunt (2013) mengemukakan bahwa bank yang memiliki leverage tinggi memiliki risiko yang tinggi pula. Apablia bank tidak mampu membayar kewajiban dan hutangnya, maka akan menimbulkan risiko, baik risiko finansial maupun non finansial, sehingga dikhawatirkan akan menurunkan nilai perusahaan. Hasil penelitian ini mendukung dengan hasil penelitian Sambora dkk. (2016) yang menemukan bahwa leverage berpengaruh negatif terhadap nilai perusahaan.

Hasil uji berdasarkan analisis jalur ( $p a t h$ ) diketahui bahwa profitabilitas berpengaruh positif dan signifikan terhadap kebijakan dividen. Hal ini dapat dilihat dari besarnya pengaruh profitabilitas terhadap kebijakan dividen yaitu sebesar 0,282 dengan signifikansi sebesar 0,081 yang lebih besar dari tingkat signifikansi yang digunakan yaitu $\alpha=0,05$ namun lebih kecil pada $\alpha$ $=0,10$. Oleh karena itu, hipotesis 3 pada penelitian ini yang menyatakan bahwa profitabilitas berpengaruh positif dan signifikan terhadap kebijakan dividen diterima. Semakin besar jumlah dana simpanan nasabah maupun jumlah kredit yang disalurkan oleh bank, semakin besar laba yang diperoleh bank, maka semakin tinggi kemungkinan bank akan mampu memenuhi kewajibannya dalam membayarkan dividen untuk pemegang saham. Semakin besar jumlah dana simpanan nasabah maupun jumlah kredit yang disalurkan oleh bank, semakin besar laba yang diperoleh bank, maka semakin tinggi kemungkinan bank akan mampu memenuhi kewajibannya dalam membayarkan dividen untuk pemegang saham. Penelitian ini mendukung dengan hasil penelitian Sunarya (2015), Migwi (2015), Sisca (2016), Tamrin et al. (2017), dan Perwira dan Wiksuana (2018) yang menemukan bahwa profitabilitas berpengaruh positif dan signifikan terhadap kebijakan dividen.

Hasil uji berdasarkan analisis jalur (path) diketahui bahwa leverage berpengaruh negatif terhadap kebijakan dividen. Hal ini dapat dilihat dari besarnya pengaruh leverage terhadap 
kebijakan dividen yaitu sebesar -0,090 dengan signifikansi sebesar 0,570 yang lebih besar dari tingkat signifikansi yang digunakan yaitu $\alpha=0,05$. Oleh karena itu, hipotesis 4 pada penelitian ini yang menyatakan bahwa leverage berpengaruh positif dan signifikan terhadap kebijakan dividen ditolak. Semakin besar dana yang dipercayakan masyarakat pada bank, maka akan semakin besar rasio hutang dibandingkan modal sendirinya. Jika bank menggunakan hutang yang tinggi, risiko perusahaan akan meningkat dan akibatnya pemegang saham akan menuntut dividen lebih tinggi untuk mengkompensasi risiko atas investasi mereka. Hasil penelitian ini tidak mendukung hasil penelitian Asif et al. (2011), Sriwahyuni dan Wihandaru (2016), Whidyasmoro dan Mahastanti (2016), dan Ikechukwu et al. (2017) yang menemukan bahwa leverage berpengaruh positif dan signifikan terhadap kebijakan dividen.

Hasil uji berdasarkan analisis jalur (path) diketahui bahwa kebijakan dividen berpengaruh negatif terhadap kebijakan dividen. Hal ini dapat dilihat dari besarnya pengaruh kebijakan dividen terhadap nilai perusahaan yaitu sebesar -0,127 dan signifikansi sebesar 0,347 yang lebih besar dari tingkat signifikansi yang digunakan yaitu $\alpha=0,05$. Oleh karena itu, hipotesis 5 pada penelitian ini yang menyatakan bahwa kebijakan dividen berpengaruh positif dan signifikan terhadap nilai perusahaan ditolak. Apabila bank tidak mampu menghasilkan laba dengan konsisten, maka manajemen tidak akan membagikan dividen. Apabila bank tidak mampu menghasilkan laba dengan konsisten, maka manajemen tidak akan membagikan dividen. Ketidak stabilan pembagian dividen pada setiap periode akan berpengaruh terhadap menurunnya harga saham. Hasil penelitian ini tidak sesuai dengan hasil penelitian yang dilakukan Afzal dan Rohman (2015), Wongso (2016), Asad dan Yousaf (2014), Nwamaka dan Ezeabasili (2017) dan Enebrand (2018) yang menemukan bahwa kebijakan dividen berpengaruh positif dan signifikan terhadap nilai perusahaan.

\section{Simpulan}

Profitabilitas berpengaruh positif dan signifikan tehadap nilai perusahaan pada sektor perbankan yang terdaftar di BEI periode tahun 2017-2019. Profitabilitas yang tinggi mencerminkan kemampuan perusahaan dalam menghasilkan laba. Jika sistem keuangan bank berjalan dengan efisien, maka akan meningkatkan profit bank. Leverage berpengaruh negative dan signikan terhadap nilai perusahaan sektor perbankan yang terdaftar di BEI periode tahun 2017-2019. Bank yang memiliki leverage tinggi akibat meminjam tambahan modal jangka pendek yang disebabkan oleh risiko kredit akan memiliki risiko yang tinggi pula. Profitabilitas berpengaruh positif dan signifikan terhadap kebijakan dividen pada sektor perbankan yang terdaftar di BEI periode tahun 2017-2019. Semakin besar jumlah dana simpanan nasabah maupun jumlah kredit yang disalurkan 
oleh bank, semakin besar laba yang diperoleh bank, maka semakin tinggi kemungkinan bank akan mampu memenuhi kewajibannya dalam membayarkan dividen untuk pemegang saham.

Leverage berpengaruh negative dan tidak signifikan terhadap kebijakan dividen pada sektor perbankan yang terdaftar di BEI periode tahun 2017-2019. Jika bank menggunakan hutang yang tinggi, risiko perusahaan akan meningkat dan akibatnya pemegang saham akan menuntut dividen lebih tinggi untuk mengkompensasi risiko atas investasi yang dilakukan. Kebijakan dividen berpengaruh negatif dan tidak signifikan terhadap nilai perusahaan pada sektor perbankan yang terdaftar di BEI periode tahun 2017-2019. Jika bank tidak mampu menghasilkan laba dengan konsisten, maka manajemen tidak akan membagikan dividen. Ketidakstabilan pembagian dividen pada setiap periode akan berpengaruh terhadap menurunnya nilai perusahaan yang berdampak pada harga saham.

\section{Daftar Pustaka}

Afzal, A., dan Rohman, A. 2012. Pengaruh Keputusan Investasi, Keputusan Pendanaan, dan Kebijakan Deviden Terhadap Nilai Perusahaan. Diponegoro Journal of Accounting, Vol. 1, No. 2

Afzal, A., dan Rohman, A. 2012. Pengaruh Keputusan Investasi, Keputusan Pendanaan, dan Kebijakan Deviden Terhadap Nilai Perusahaan. Diponegoro Journal of Accounting, Vol. 1, No. 2

Asad Muhammad dan SaddiaYousaf (2014) Impact of Leverage on Dividend Payment Behavior of Pakistani Manufacturing Firms. International Journal of Innovation and Applied Studies, No. 6, Vol. 2.

Asif Aasia, Rasool,Waqas, dan Kama,Yasir. 2011. Impact of financial leverage on dividend policy: Empirical evidence from Karachi Stock Exchange-listed Companies. African Journal of Business Management, Vol. 5(4), pp. 1312-1324, 18 February, 2011.

Bressan, Silvia. 2017. The Interplay between Dividends and Leverage inside Commercial Banks. International Journal of Financial Research, Vol. 8, No. 2, 2017.

Enebrand Adam, 2018. Dividend policy and its impact on firm valuation. Master thesis within: Finance Number of credits: 30 ECTS Programme of study: Civilekonomprogrammet, 2018.

Hakim Luqman dan Sugianto, 2018. Determinant Profitability and Implications on the Value of the Company: Empirical Study on Banking Industry in IDX. International Journal of Economics and Financial Issues, 2018.

Husnan, Suad dan Pudjiastuti Enny (2015), Dasar-Dasar Manajemen Keuangan, Penerbit UPP STIM YKPN, Yogyakarta.

Ikechukwu Amahalu, Okoye Emmanuel, Nestor Ndubuisi.,dan Nweze Chike Leonard Obi Juliet Chinyere. Effect of Financial Leverage on Dividend Policy of Quoted Conglomerates (20102015).

Kohlsceen,E., Murcia,A., dan Contreas,J. 2018. Determinants of bank profitability in emerging markets. Bank for International Settlements 2018.

Martini Putu, Moeljadi, Djumahir, dan Atim Djazuli, 2014. Factors Affecting Firms Value of Indonesia Public Manufacturing Firms. International Journal of Business and Management Invention, Volume 3, Issue 2 February. 
Migwi, Warware, Elizabeth. 2015. The Effect Of Profitability on Dividend Policy of Commercial Banks in Kenya. International Journal of Business and Management Invention, Volume 5, Issue.

Munawir, S. 2002. Analisa Laporan Keuangan. Yogyakarta: Liberty Yogyakarta.

Naceur, S. B. dan Goaied, M., 2002. The relationship between dividend policy,financial structure, profitability and firm value. Applied Financial Economics, Vol. 12, Pp. 843-849.

Nwamaka, Ozuomba Chidinma dan Prof. Ezeabasili. 2017. Effect of Dividend Policies on Firm Value: Evidence from quoted firms in Nigeria. International Journal of Management Excellence, Volume 8 No.2 February 2017.

Onyenwe Nwanna Ifeanyi dan Ivie Glory, 2017. Effect Of Financial Leverage On Firms Performance: A Study Of Nigerian Banks (2006 -2015). International Journal of Recent Scientific Research Vol. 8, Issue, 7, pp. 18554-18564, July, 2017.

Perwira Nanda A.A.G. dan Wiksuana, I G.B., 2018. Pengaruh Profitabilitas Dan Pertumbuhan Aset Terhadap Kebijakan Dividen Dan Nilai Perusahaan. E-Jurnal Manajemen Unud, Vol. 7, No. 7, 2018.

Riduwan dan Engkos Ahmad Kuncoro, 2011. Cara menggunakan dan memakai Puth Analysis (Analisis Jalur) Edisi Revisi. Cetakan ketiga, Bandung: Alfabeta

Sambora, M.N., Handayani, S.R., dan Rahayu, S.M. 2016. Pengaruh leverage dan profitabilitas terhadap nilai perusahaan. Jurnal Administrasi Bisnis (JAB)/Nol. 8 No. 1 Februari 2014.

Sartono, A., 2014. Manajemen Keuangan. Yogyakarta: Fakultas Ekonomi \& Bisnis UGM

Sisca, 2016. Pengaruh Leverage Dan Profitabilitas Terhadap Nilai Perusahaan Dengan Kebijakan Dividen Sebagai Variabel Moderating Pada Perusahaan Manufaktur Yang Terdaftar Di BEI Tahun 2010 - 2014. Jurnal SULTANIST, Vol. 4 No.1, Juni 2016.

SriwahyuniUlfa dan Wihandaru, 2016. Pengaruh profitabilitas, Leverage, Kepemilikan Institusional, dan Investment opportunity Set terhadap Nilai perusahaan dengan kebijakan dividen sebagai Variabel Intervening pada Perusahaan manufaktur yang terdaftar di BEI. Volume 7, No.1 Maret 2016.

Sucuahi William dan Cambarih Jay Mark, 2016. Influence of Profitability to the Firm Value of Diversified Companies in the Philippines. Accounting and Finance Research, Vol. 5, No. 2; 2016.

Sugiyono. 2010. Metode Penelitian Bisnis. Bandung: CV. Alfabeta.

Sujoko dan Soebiantoro. 2016. Pengaruh Kepemilikan saham, Leverage, Faktor Intern dan Faktor Eksern Nilai Perusahaan (Studi mpirik pada Perusahaan Manufaktur di Bursa Efek Jakarta). Jurnal Manajemen dan Kewirausahaan, volume 9, 1 Maret 2007, h: 41-48

Sunarya, D.H. 2015. Pengaruh Kebijakan Utang, Profitabilitas, dan Likuiditas terhadap Kebijakan Dividen dengan Size sebagai variabel moderasi pada sektor Manufaktur periode 2008-2011. Jurnal Ilmiah Mahasiswa Universitas Surabaya Vol. 2 no. 1 (2013).

Tamrin, Muhamad., Mus, Rahman., and Arfah, Aryati. 2017. Effect of profitability and dividend policy on corporate governance and firm value: Evidence from the Indonesian manufacturing Sectors. IOSR Journal of Business and Management (IOSR-JBM), Volume 19, Issue 10. (October. 2017).

Velnampy, T. P. Nimalthasan \& K. Kalaiarasi, 2014. Dividend Policy and Firm Performance: Evidence from the Manufacturing Companies Listed on the Colombo Stock Exchange. Global Journal of Management and Business Research: A Administration and Management, Volume 14 Issue 6 Version 1.0 Year 2014.

Whidyasmoro Ivan dan Linda Ariani Mahastanti, Analisis Pengaruh Kebijakan Hutang, Profitabilitas, Likuiditas, Kesempatan Investasi, dan Jenis Industri Terhadap Kebijakan Dividen. Fakultas Ekonomi dan Bisnis, Universitas Satya Wacana. 
Wijaya, Bayu Irfandi dan I.B. Pandji Sedana, 2015. Pengaruh Profitabilitas Terhadap Nilai Perusahaan (Kebijakan Dividen Dan Kesempatan Investasi Sebagai Variabel Mediasi). EJurnal Manajemen Unud, Vol. 4, No.12, Pp. 4477-4500.

Wongso, A. 2016. Pengaruh Kebijakan dividen, struktur kepemilikan dan kebijakan hutang terhadap nilai perusahaan dalam perspektif teori Agensi dan teori signaling. Jurnal Universitas Katolik Widya Mandala Surabaya. www.idx.co.id 